\title{
Guidelines for the Treatment of Latent Tuberculosis Infection: Recommendations from the National Tuberculosis Controllers Association and CDC, 2020
}




\section{CONTENTS}

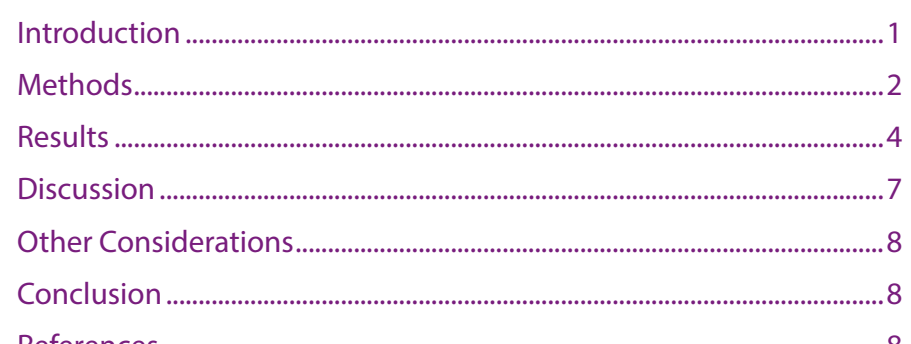

References......................................................................................................

The MMWR series of publications is published by the Center for Surveillance, Epidemiology, and Laboratory Services, Centers for Disease Control and Prevention (CDC), U.S. Department of Health and Human Services, Atlanta, GA 30329-4027.

Suggested citation: [Author names; first three, then et al., if more than six.] [Title]. MMWR Recomm Rep 2020;69(No. RR-\#):[inclusive page numbers].

\section{Centers for Disease Control and Prevention}

Robert R. Redfield, MD, Director

Anne Schuchat, MD, Principal Deputy Director

Chesley L. Richards, MD, MPH, Deputy Director for Public Health Science and Surveillance

Rebecca Bunnell, PhD, MEd, Director, Office of Science

Arlene Greenspan, PhD, MS, Acting Director, Office of Science Quality, Office of Science

Michael F. Iademarco, MD, MPH, Director, Center for Surveillance, Epidemiology, and Laboratory Services

\section{MMWR Editorial and Production Staff (Serials)}

Charlotte K. Kent, PhD, MPH, Editor in Chief Christine G. Casey, MD, Editor

Mary Dott, MD, MPH, Online Editor

Terisa F. Rutledge, Managing Editor

David C. Johnson, Lead Technical Writer-Editor

Catherine B. Lansdowne, MS, Project Editor

Ileana Arias, $\mathrm{PhD}$

Matthew L. Boulton, MD, MPH

Jay C. Butler, MD

Virginia A. Caine, MD

Katherine Lyon Daniel, PhD
MMWR Editorial Board

Timothy F. Jones, MD, Chairman

Jonathan E. Fielding, MD, MPH, MBA

David W. Fleming, MD

William E. Halperin, MD, DrPH, MPH

Jewel Mullen, MD, MPH, MPA

Jeff Niederdeppe, $\mathrm{PhD}$

Patricia Quinlisk, MD, MPH
Martha F. Boyd, Lead Visual Information Specialist Maureen A. Leahy, Julia C. Martinroe, Stephen R. Spriggs, Tong Yang, Visual Information Specialists

Quang M. Doan, MBA, Phyllis H. King, Terraye M. Starr, Moua Yang, Information Technology Specialists

Stephen C. Redd, MD

Patrick L. Remington, MD, MPH

Carlos Roig, MS, MA

William Schaffner, MD

Morgan Bobb Swanson, BS 


\title{
Guidelines for the Treatment of Latent Tuberculosis Infection: Recommendations from the National Tuberculosis Controllers Association and CDC, 2020
}

\author{
Timothy R. Sterling, $\mathrm{MD}^{1}$; Gibril Njie, MPH${ }^{2}$; Dominik Zenner, MD ${ }^{3}$; David L. Cohn, MD ${ }^{4}$; Randall Reves, MD; \\ Amina Ahmed, MD; Dick Menzies, MD6; C. Robert Horsburgh, Jr., MD7; Charles M. Crane, MD; Marcos Burgos, MD ${ }^{8,9}$; Philip LoBue, MD²; \\ Carla A. Winston, $\mathrm{PhD}^{2}$; Robert Belknap, $\mathrm{MD}^{4,8}$

\begin{abstract}
${ }^{1}$ Vanderbilt University Medical Center, Nashville, Tennessee; ${ }^{2}$ National Center for HIVIAIDS, Viral Hepatitis, STD, and TB Prevention, Division of Tuberculosis Elimination, CDC, Atlanta, Georgia; ${ }^{3}$ Institute for Global Health, University College London, London, England; ${ }^{4}$ Denver Health and Hospital Authority, Denver, Colorado; ${ }^{5}$ Levine Children's Hospital, Charlotte, North Carolina; ${ }^{6}$ Montreal Chest Institute and McGill International TB Centre, Montreal, Canada; ${ }^{7}$ Boston University Schools of Public Health and Medicine, Boston, Massachusetts; ${ }^{8}$ National Tuberculosis Controllers Association, Smyrna, Georgia;

${ }^{9}$ University of New Mexico Health Science Center and New Mexico Department of Health, Albuquerque, New Mexico
\end{abstract}

\section{Summary}

Comprehensive guidelines for treatment of latent tuberculosis infection (LTBI) among persons living in the United States were last published in 2000 (American Thoracic Society. CDC targeted tuberculin testing and treatment of latent tuberculosis infection. Am J Respir Crit Care Med 2000;161:S221-47). Since then, several new regimens have been evaluated in clinical trials. To update previous guidelines, the National Tuberculosis Controllers Association (NTCA) and CDC convened a committee to conduct a systematic literature review and make new recommendations for the most effective and least toxic regimens for treatment of LTBI among persons who live in the United States.

The systematic literature review included clinical trials of regimens to treat LTBI. Quality of evidence (high, moderate, low, or very low) from clinical trial comparisons was appraised using the Grading of Recommendations Assessment, Development, and Evaluation (GRADE) criteria. In addition, a network meta-analysis evaluated regimens that had not been compared directly in clinical trials. The effectiveness outcome was tuberculosis disease; the toxicity outcome was hepatotoxicity. Strong GRADE recommendations required at least moderate evidence of effectiveness and that the desirable consequences outweighed the undesirable consequences in the majority of patients. Conditional GRADE recommendations were made when determination of whether desirable consequences outweighed undesirable consequences was uncertain (e.g., with low-quality evidence).

These updated 2020 LTBI treatment guidelines include the NTCA- and CDC-recommended treatment regimens that comprise three preferred rifamycin-based regimens and two alternative monotherapy regimens with daily isoniazid. All recommended treatment regimens are intended for persons infected with Mycobacterium tuberculosis that is presumed to be susceptible to isoniazid or rifampin. These updated guidelines do not apply when evidence is available that the infecting $\mathrm{M}$. tuberculosis strain is resistant to both isoniazid and rifampin; recommendations for treating contacts exposed to multidrug-resistant tuberculosis were published in 2019 (Nahid P, Mase SR Migliori GB, et al. Treatment of drug-resistant tuberculosis. An official ATS/CDC/ERS/IDSA clinical practice guideline. Am J Respir Crit Care Med 2019;200:e93-e142). The three rifamycin-based preferred regimens are 3 months of once-weekly isoniazid plus rifapentine, 4 months of daily rifampin, or 3 months of daily isoniazid plus rifampin. Prescribing providers or pharmacists who are unfamiliar with rifampin and rifapentine might confuse the two drugs. They are not interchangeable, and caution should be taken to ensure that patients receive the correct medication for the intended regimen. Preference for these rifamycin-based regimens was made on the basis of effectiveness, safety, and high treatment completion rates. The two alternative treatment regimens are daily isoniazid for 6 or 9 months; isoniazid monotherapy is efficacious but has higher toxicity risk and lower treatment completion rates than shorter rifamycin-based regimens.

In summary, short-course (3- to 4-month) rifamycin-based treatment regimens are preferred over longer-course (6-9 month) isoniazid monotherapy for treatment of LTBI. These updated guidelines can be used by clinicians, public health officials, policymakers, health care organizations, and other state and local stakeholders who might need to adapt them to fit individual clinical circumstances.

\section{Introduction}

Corresponding author: Carla A. Winston, National Center for HIV/AIDS, Viral Hepatitis, STD, and TB Prevention, Division of Tuberculosis Elimination, CDC. Telephone: 404-718-8008; E-mail: CWinston@cdc.gov.
One fourth of the global population (approximately 2 billion persons) is estimated to be infected with Mycobacterium tuberculosis (1), including approximately 13 million in the United States (2). Most infected persons are asymptomatic 
and classified as having latent tuberculosis infection (LTBI). If untreated, approximately $5 \%-10 \%$ of persons with LTBI progress to tuberculosis (TB) disease during their lifetime (3-5). Progression from untreated LTBI accounts for approximately $80 \%$ of U.S. TB disease cases ( 6 ). Treatment of LTBI is effective in preventing progression to $\mathrm{TB}$ disease $(7)$. The most recent comprehensive guidelines for treatment of LTBI in the United States were published in 2000 (8). In 2003, CDC and the American Thoracic Society recommended against use of the 2-month regimen of rifampin plus pyrazinamide because of the risk for severe hepatotoxicity (9). Since then, several new regimens have been evaluated in clinical trials. To update the 2000 and 2003 treatment guidelines, the National Tuberculosis Controllers Association (NTCA) and CDC convened a committee to conduct a systematic literature review of clinical trials for the treatment of LTBI. Grading of Recommendations Assessment, Development, and Evaluation (GRADE) criteria were applied to the evidence of effectiveness, a network metaanalysis of selected evidence was performed, and the evidence was used to support 2020 LTBI treatment guidelines.

These updated 2020 LTBI treatment guidelines apply to persons with LTBI who live in the United States. In addition, these guidelines apply to persons infected with $M$. tuberculosis that is presumed to be susceptible to isoniazid or rifampin; they do not apply when evidence is available that the infecting M. tuberculosis strain is resistant to both isoniazid and rifampin. Local and state TB programs in the United States answer questions about diagnosing and treating persons with LTBI in their jurisdictions (http://www.tbcontrollers.org).

\section{Methods}

These updated guidelines were developed by NTCA and CDC. The LTBI treatment guidelines committee members, who are the authors of this report, were nominated on the basis of their expertise in treatment of LTBI. The committee had expertise in epidemiology, domestic and international TB control, clinical trials, and treatment of LTBI in adults and children. A methodologist with expertise in the GRADE approach served as a consultant to the guideline development committee.

\section{Evidence Search}

The committee determined that the following clinical question should be addressed in the updated guidelines: "Which regimens for treatment of latent tuberculosis infection have the greatest effectiveness and least toxicity?" The question was written in the population, intervention, comparator, outcomes (PICO) format, and then the outcomes were rated as critical, important, or not important. Comparison of regimen toxicities was limited to hepatotoxicity because this was the only toxicity that could be consistently compared across studies.

A systematic literature review was initiated in December 2017. Electronic databases including MEDLINE, Embase, CINAHL, ClinicalTrials.gov, the Cochrane Central Register of Controlled Trials (CENTRAL), and gray literature were searched for studies evaluating the effectiveness of LTBI treatment regimens. Search terms included "latent tuberculosis," "latent TB," "LTBI," "Mycobacterium tuberculosis," "tuberculosis infection" AND "isoniazid," "rifampin," "rifapentine," or "pyrazinamide." Articles were included if the study design was a randomized controlled trial and outcomes included prevention of TB disease and drug-related hepatotoxicity. Studies that included persons with suspected or confirmed TB disease were excluded from the review.

The initial search located a high-quality systematic review and meta-analysis published in August 2017 that examined the effectiveness of LTBI treatment regimens (10). The study authors were contacted and asked for access to the extracted data. Study characteristics, types of participants, interventions, the outcomes measured, and results were extracted from each study. If the data were amenable to pooling, effects were estimated via meta-analysis. For the meta-analyses, a random effects model was used unless otherwise specified, and effect estimates were reported as odds ratios. All statistical analyses were conducted using the "metafor" package in R, versions 3.4.3 (11). The Cochrane risk-of-bias tool was used to conduct a bias assessment (12). Analyses conducted in 2018 included combined data from the studies in the previous review and articles identified during an updated search for studies published during June 2017-August 2018 (Figure) (13,14).

All treatment regimens were analyzed using a Bayesian network meta-analysis (NMA) approach, which allowed for indirect comparisons of treatment regimens when direct comparisons were not available. However, direct, pairwise meta-analysis was the preferred method; the results of the network analysis are presented in this report only if no direct comparisons were available. A full description of the network analysis method has been previously published $(10,15)$. NMA allows for indirect comparisons of treatment regimens through inference from a network of evidence. For this analysis, WinBUGS software (version 1.4; Medical Research Council Biostatistics Unit of the University of Cambridge) was used to create the Bayesian network with posterior distributions on the basis of 20,000 samples after a burn-in period of 10,000 iterations (15). Convergence was assessed by inspecting parameter chains and the Gelman-Rubin diagnostic (16). Summary statistics and $95 \%$ credible intervals were obtained from posterior distributions. Network inconsistency, which 
FIGURE. Systematic literature review search process* for latent tuberculosis infection treatment regimens recommended by the National Tuberculosis Controllers Association and CDC, 2020

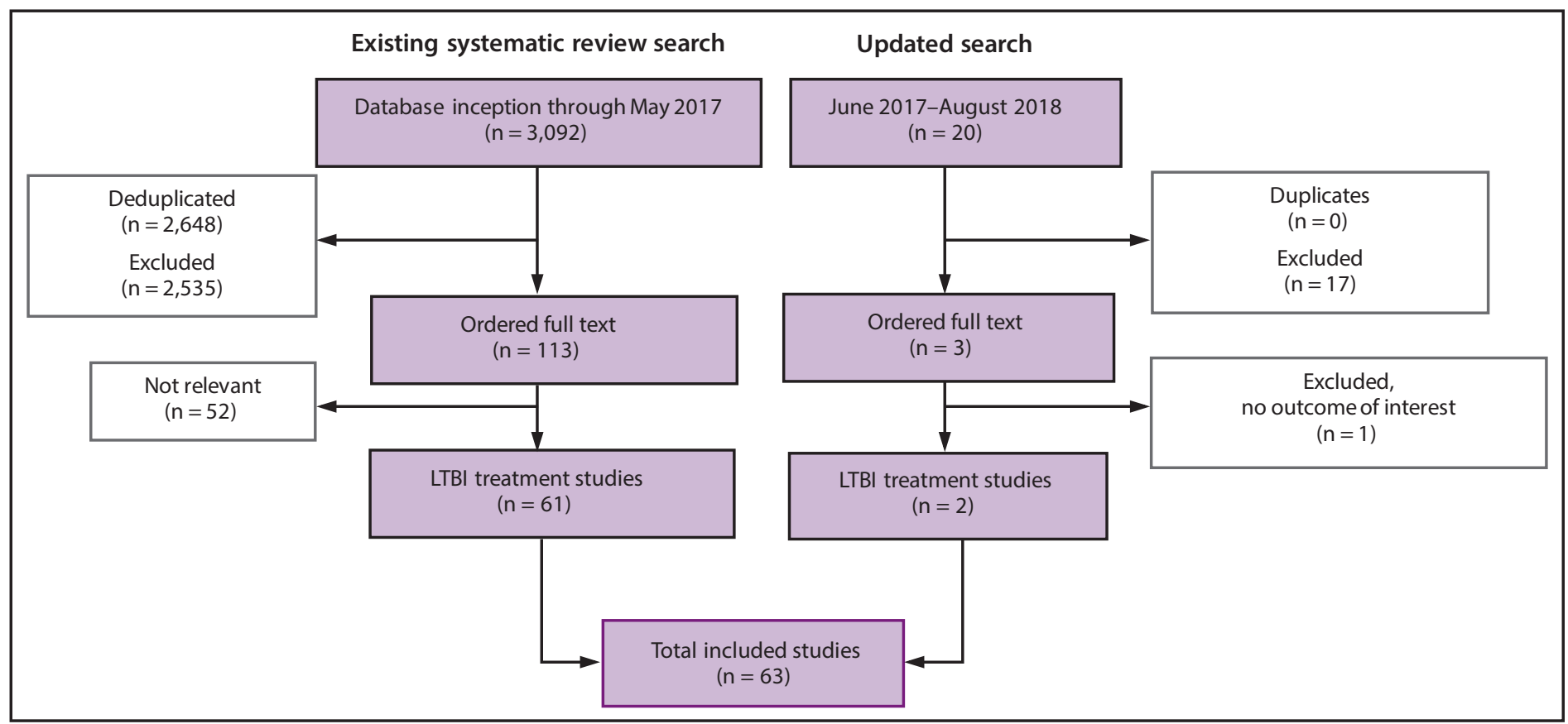

Abbreviation: $\mathrm{LTBI}=$ latent tuberculosis infection.

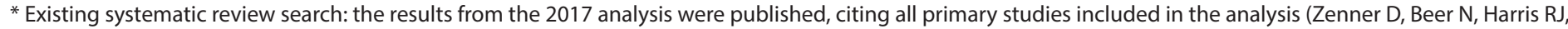

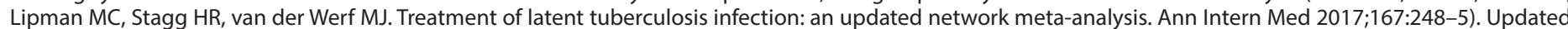

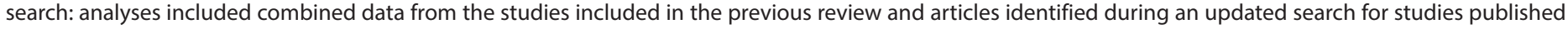
during June 2017-August 2018.

can arise if indirect comparisons conflict with direct pairwise estimates, was assessed by comparison with standard metaanalysis and by using the omnibus test for consistency (17).

The overall quality of evidence was appraised using the GRADE approach, and GRADEpro software was used to develop evidence profiles that summarized the quality of evidence for each outcome (high, moderate, low, or very low) and the rationale for the quality of evidence appraisal (18). Headto-head comparisons of regimens evaluated in clinical trials were evaluated according to the populations studied: adults, children, HIV positive, and HIV negative. References for all of the studies included in the analyses are available (Supplementary Tables; https://stacks.cdc.gov/view/cdc/84235).

\section{Development of Recommendations}

The committee discussed evidence during face-to-face meetings and teleconferences. GRADE evidence tables were prioritized according to the regimens, comparisons, and study populations that were deemed most clinically relevant to the United States. If discrepancies between GRADE head-tohead comparisons and network meta-analysis results were found, the committee prioritized the GRADE comparisons. Recommendations were formulated on the basis of the following considerations: the balance of desirable consequences of the intervention (benefits) and undesirable consequences (regimen complexity, adverse effects, and cost), the quality of evidence, patient values and preferences, and feasibility (19). The desirable and undesirable consequences considered by the committee included both those related to individuals and to overall public health.

A strong GRADE recommendation for a regimen was made if the panel concluded that the desirable consequences of the intervention outweighed the undesirable consequences, the majority of well-informed patients would choose the regimen, and the evidence was at least moderate quality $(18,19)$. A conditional GRADE recommendation was made for a regimen when uncertainty existed regarding whether the desirable consequences outweighed the undesirable consequences (e.g., low-quality evidence for a critical outcome such that additional evidence could change key findings, hence the recommendation) $(18,19)$. A conditional recommendation indicates that well-informed patients might make different choices regarding whether to choose the regimen $(18,19)$.

The panel also prioritized recommended regimens as either preferred or alternative. Preferred regimens were defined as having excellent tolerability and efficacy, shorter treatment duration, and higher completion rates. Alternative regimens 
were defined as having excellent efficacy but longer treatment duration and lower completion rates. The rationale for prioritizing the regimens was that treatment completion rates are higher with shorter regimens (20); if regimens have similar efficacy and safety, the shorter regimen is more effective because completion rates are higher.

Draft recommendations were publicly presented during the U.S. Advisory Council on the Elimination of Tuberculosis meeting on December 11, 2018, and at the NTCA meeting on April 23, 2019. The recommendations were positively received at both meetings, and no substantive changes were made to the recommendations thereafter.

\section{Results}

The GRADE evidence tables are provided (Table 1) (Supplementary Tables; https://stacks.cdc.gov/view/ cdc/84235). The Supplementary Tables contain all references; selected references are included in this report. In total, 55 clinical trials evaluated effectiveness $(7,13,14,21-74)$, and 31 trials evaluated toxicity $(13,14,27,35-38,43-$ $46,49,51-53,55,61-66,68,71,72,75-82)$. Results of the 2018 updated network meta-analysis are provided (Table 2); 63 studies of 16 regimens were evaluated $(7,13,14,21-82)$.

\section{Summary of Evidence and Recommendations}

The recommended treatment regimens include three preferred and two alternative treatment regimens (Tables 3 and 4). Rifamycin-based regimens, including 3 months of once-weekly isoniazid plus rifapentine, 4 months of daily rifampin, and 3 months of daily isoniazid plus rifampin are the preferred recommended regimens because of their effectiveness, safety, and high treatment completion rates. Regimens of 6 or 9 months of daily isoniazid are alternative recommended regimens; although efficacious, they have higher toxicity risk and lower treatment completion rates, which decrease effectiveness. On the basis of the most recent comprehensive LTBI treatment guidelines in the United States, which were published in 2000 (8), 9 months of daily isoniazid was considered the standard comparator regimen to evaluate shorter-course regimens. Data on the effectiveness and toxicity of 9 months of daily isoniazid are provided, as are data on the other recommended regimens. A rifamycin-based regimen refers to treatment that includes either rifampin or rifapentine.

\section{Preferred Regimens}

\section{Three Months of Weekly Isoniazid Plus Rifapentine}

A regimen of 3 months of once-weekly isoniazid plus rifapentine is a preferred regimen that is strongly recommended for adults and children aged $>2$ years, including HIVpositive persons (as drug interactions allow). This regimen, administered through directly observed therapy, had equivalent effectiveness and was not more toxic than the standard regimen of 9 months of daily isoniazid in adults and children aged $>2$ years $(53,68,83)$. Treatment completion rates were higher with the 3-month regimen. In HIV-negative persons in a noninferiority study, 3 months of isoniazid and rifapentine was equivalent to and was associated with less hepatoxicity than 9 months of isoniazid, despite more discontinuation because of adverse effects (68). In HIV-positive persons, no significant difference was found in a comparison of isoniazid plus rifapentine for all outcomes with either 6 or 9 months of isoniazid $(22,53)$. In a noninferiority study of 3 months of weekly isoniazid plus rifapentine, the completion rate by self-administered therapy was inferior to the rate with direct observation but noninferior in the prespecified subpopulation from the United States (84).

Potential disadvantages of this regimen include cost of medications that are greater than most alternatives, potential added costs if provided by directly observed therapy (with treatment completion being highest with directly observed therapy, although self-administered therapy is an approved option) (85), the need to take numerous pills simultaneously (10 pills once weekly compared with two or three pills daily for other regimens for most adults), and the association with a systemic drug reaction or influenza-like syndrome that can include syncope and hypotension. Severe events requiring hospitalization occurred in $0.1 \%$ of persons $(68,86)$. The systemic drug reaction is self-limited and usually mild; no deaths have been reported. Potential drug interactions and acquired drug resistance if TB disease is not adequately excluded also are important considerations for all treatment regimens.

\section{Four Months of Daily Rifampin}

A regimen of 4 months of daily rifampin is a preferred treatment that is strongly recommended for HIV-negative adults and children of all ages. (No evidence is available for effectiveness in HIV-positive persons.) The effectiveness of this regimen was clinically equivalent to, and less toxic than, the standard regimen of 9 months of daily isoniazid in adults and children $(13,14,78,79)$. Four months of daily rifampin had noninferior effectiveness in preventing TB disease compared with 9 months of daily isoniazid, as well as a lower rate of treatment discontinuation because of 
TABLE 1. Summary of GRADE evidence tables, by treatment regimen and study population*

\begin{tabular}{|c|c|c|c|c|}
\hline \multicolumn{2}{|l|}{ Regimen } & \multirow[b]{2}{*}{ Population } & \multicolumn{2}{|c|}{ No. of trials } \\
\hline Experimental regimen & Comparator regimen & & Effectiveness & Toxicity \\
\hline 3 mos isoniazid plus rifapentine given once weekly & 9 mos isoniazid & HIV-positive adults & 1 & 1 \\
\hline 3 mos isoniazid plus rifapentine given once weekly & 9 mos isoniazid & HIV-negative adults and children & 1 & 1 \\
\hline 3 mos isoniazid plus rifapentine given once weekly & 9 mos isoniazid & HIV-negative children & 1 & 1 \\
\hline 3 mos isoniazid plus rifapentine given once weekly & 6 mos isoniazid & HIV-positive adults & 1 & 1 \\
\hline 3 mos isoniazid plus rifampin given daily & 9 mos isoniazid & HIV-negative adults & 1 & 1 \\
\hline 3 mos isoniazid plus rifampin given daily & 6 mos isoniazid & HIV negative adults and children & 3 & 2 \\
\hline 3 mos isoniazid plus rifampin given daily & 6 mos isoniazid & HIV-positive adults & 4 & 4 \\
\hline 3 mos isoniazid plus rifampin given daily & Placebo or no treatment & HIV-positive adults & 2 & 1 \\
\hline 3 mos isoniazid plus rifampin given daily & Placebo or no treatment & HIV-negative adults and children & 2 & 0 \\
\hline 4 mos rifampin given daily & 9 mos isoniazid & HIV-negative adults & 1 & 2 \\
\hline 4 mos rifampin given daily & 9 mos isoniazid & HIV-negative children & 1 & 1 \\
\hline 4 mos rifampin given daily & 6 mos isoniazid & HIV-negative children & 1 & 0 \\
\hline 6 mos isoniazid given daily & Placebo & HIV-negative adults and children & 4 & 2 \\
\hline 6 mos isoniazid given daily & Placebo or no treatment & HIV-positive adults & 5 & 3 \\
\hline 9 mos isoniazid given daily & No treatment & HIV-negative adults and children & 2 & 0 \\
\hline 12 mos isoniazid given daily & No treatment & HIV-positive adults & 2 & 0 \\
\hline 12 mos isoniazid given daily & Placebo & HIV-positive adults and children & 5 & 3 \\
\hline 12 mos isoniazid given daily & Placebo & HIV-positive children & 3 & 1 \\
\hline 12 mos isoniazid given daily & Placebo or no treatment & HIV-negative adults and children & 15 & 5 \\
\hline 3 mos isoniazid plus rifapentine given once weekly & Continuous isoniazid (up to 6 yrs) & HIV-positive adults & 1 & 1 \\
\hline $\begin{array}{l}2 \text { mos rifampin and pyrazinamide given daily or } \\
\text { twice weekly }\end{array}$ & 6 mos isoniazid, 12 mos isoniazid & HIV-positive adults and children & 4 & 2 \\
\hline
\end{tabular}

Abbreviation: GRADE = Grading of Recommendations Assessment, Development, and Evaluation.

* Study details and information on evidence quality are available (Supplementary Tables; https://stacks.cdc.gov/view/cdc/84235).

TABLE 2. Network meta-analysis of regimens to treat latent tuberculosis infection

\begin{tabular}{|c|c|c|}
\hline & $2017^{*}$ & 2018 update (unpublished) \\
\hline Risk and treatment & Odds ratio ( $95 \%$ credible interval) & Odds ratio ( $95 \%$ credible interval) \\
\hline \multicolumn{3}{|l|}{ Tuberculosis risk compared with no treatment } \\
\hline No treatment & 1 (ref) & 1 (ref) \\
\hline 3 mos isoniazid plus rifapentine given once weekly & $0.36(0.18-0.73)$ & $0.36(0.18-0.72)$ \\
\hline 3-4 mos rifampin given daily & $0.25(0.11-0.57)$ & $0.25(0.12-0.50)$ \\
\hline 3 mos isoniazid plus rifampin given daily & $0.33(0.20-0.54)$ & $0.33(0.20-0.53)$ \\
\hline 6 mos isoniazid given daily & $0.40(0.26-0.60)$ & $0.40(0.26-0.59)$ \\
\hline 9 mos isoniazid given daily & $0.46(0.22-0.95)$ & $0.47(0.24-0.90)$ \\
\hline \multicolumn{3}{|l|}{ Hepatotoxicity risk compared with no treatment } \\
\hline No treatment & 1 (ref) & 1 (ref) \\
\hline 3 mos isoniazid plus rifapentine given once weekly & $0.52(0.13-2.15)$ & $0.53(0.13-2.13)$ \\
\hline 3-4 mos rifampin given daily & $0.14(0.02-0.81)$ & $0.13(<0.02-0.72)$ \\
\hline 3 mos isoniazid plus rifampin given daily & $0.72(0.21-2.37)$ & $0.73(0.22-2.38)$ \\
\hline 6 mos isoniazid given daily & $1.10(0.40-3.17)$ & $1.11(0.41-3.15)$ \\
\hline 9 mos isoniazid given daily & $1.70(0.35-8.05)$ & $1.77(0.35-8.32)$ \\
\hline
\end{tabular}

Abbreviation: ref $=$ referent.

* The results from the 2017 analysis were published, citing all primary studies included in the analysis (Zenner D, Beer N, Harris RJ, Lipman MC, Stagg HR, van der Werf MJ. Treatment of latent tuberculosis infection: an updated network meta-analysis. Ann Intern Med 2017;167:248-55.); the 2018 update includes data subsequently published (Diallo T, Adjobimey M, Ruslami R, et al. Safety and side effects of rifampin versus isoniazid in children. N Engl J Med 2018;379:454-63; Menzies D, Adjobimey M, Ruslami R, et al. Four months of rifampin or nine months of isoniazid for latent tuberculosis in adults. N Engl J Med 2018;379:440-53).

adverse effects, a lower rate of hepatotoxicity, and a higher rate of treatment completion $(13,14)$.

The potential disadvantages of the rifamycin-based regimens are the many drug interactions, including warfarin, oral contraceptives, azole antifungals, and HIV antiretroviral therapy (87). Rifabutin has fewer or less pronounced drug interactions and may be used in place of rifampin when rifampin is contraindicated due to drug-drug interactions and isoniazid cannot be used (87). Drug interactions with weekly rifapentine are fewer than with rifampin and appear to be fewer than with rifabutin; therefore, weekly isoniazid and rifapentine could be considered when rifampin is contraindicated, although clinical data are limited (88). Drugdrug interactions between rifamycins and antiretroviral therapy are regularly updated by the U.S. Department of Health and Human Services (https://aidsinfo.nih.gov/guidelines/html/4/ adult-and-adolescent-opportunistic-infection/0). In HIVpositive persons with low $\mathrm{CD} 4+$ lymphocyte counts, the risk 
TABLE 3. Recommendations for regimens to treat latent tuberculosis infection

\begin{tabular}{|c|c|c|c|}
\hline Priority rank* & Regimen & $\begin{array}{c}\text { Recommendation } \\
\text { (strong or conditional) }\end{array}$ & $\begin{array}{c}\text { Evidence } \\
\text { (high, moderate, low, or very low) }\end{array}$ \\
\hline Preferred & 3 mos isoniazid plus rifapentine given once weekly & Strong & Moderate \\
\hline Preferred & 4 mos rifampin given daily & Strong & Moderate (HIV negative) ${ }^{\dagger}$ \\
\hline \multirow[t]{2}{*}{ Preferred } & 3 mos isoniazid plus rifampin given daily & Conditional & Very low (HIV negative) \\
\hline & & Conditional & Low (HIV positive) \\
\hline \multirow[t]{2}{*}{ Alternative } & 6 mos isoniazid given daily & Strong ${ }^{\S}$ & Moderate (HIV negative) \\
\hline & & Conditional & Moderate (HIV positive) \\
\hline Alternative & 9 mos isoniazid given daily & Conditional & Moderate \\
\hline
\end{tabular}

Abbreviation: HIV = human immunodeficiency virus.

* Preferred: excellent tolerability and efficacy, shorter treatment duration, higher completion rates than longer regimens and therefore higher effectiveness; alternative: excellent efficacy but concerns regarding longer treatment duration, lower completion rates, and therefore lower effectiveness.

† No evidence reported in HIV-positive persons.

$\S$ Strong recommendation for those persons unable to take a preferred regimen (e.g., due to drug intolerability or drug-drug interactions).

TABLE 4. Dosages for recommended latent tuberculosis infection treatment regimens

\begin{tabular}{|c|c|c|c|c|}
\hline Drug & Duration & Dose and age group & Frequency & Total doses \\
\hline Isoniazid* and rifapentine $^{\dagger}$ & $3 \mathrm{mos}$ & $\begin{array}{l}\text { Adults and children aged } \geq 12 \text { yrs } \\
\text { Isoniazid: } 15 \mathrm{mg} / \mathrm{kg} \text { rounded up to the nearest } 50 \text { or } 100 \mathrm{mg} ; 900 \mathrm{mg} \text { maximum } \\
\text { Rifapentine: } \\
10-14.0 \mathrm{~kg}, 300 \mathrm{mg} \\
14.1-25.0 \mathrm{~kg}, 450 \mathrm{mg} \\
25.1-32.0 \mathrm{~kg}, 600 \mathrm{mg} \\
32.1-49.9 \mathrm{~kg}, 750 \mathrm{mg} \\
\geq 50.0 \mathrm{~kg}, 900 \mathrm{mg} \text { maximum } \\
\text { Children aged } 2-11 \text { yrs } \\
\text { Isoniazid*: } 25 \mathrm{mg} / \mathrm{kg} ; 900 \mathrm{mg} \text { maximum } \\
\text { Rifapentine }{ }^{\dagger}: \text { see above }\end{array}$ & Once weekly & 12 \\
\hline Rifampin? & $4 \mathrm{mos}$ & $\begin{array}{l}\text { Adults: } 10 \mathrm{mg} / \mathrm{kg} \\
\text { Children: } 15-20 \mathrm{mg} / \mathrm{kg}^{* *} \\
\text { Maximum dose: } 600 \mathrm{mg}\end{array}$ & Daily & 120 \\
\hline Isoniazid* and rifampin & $3 \mathrm{mos}$ & $\begin{array}{l}\text { Adults } \\
\text { Isoniazid*: } 5 \mathrm{mg} / \mathrm{kg} ; 300 \mathrm{mg} \text { maximum } \\
\text { Rifampin } 9: 10 \mathrm{mg} / \mathrm{kg} ; 600 \mathrm{mg} \text { maximum } \\
\text { Children } \\
\text { Isoniazid*: } 10-20 \mathrm{mg} / \mathrm{kg}^{\dagger+} ; 300 \mathrm{mg} \text { maximum } \\
\text { Rifampin": } 15-20 \mathrm{mg} / \mathrm{kg}^{+} 600 \mathrm{mg} \text { maximum }\end{array}$ & Daily & 90 \\
\hline \multirow[t]{2}{*}{ Isoniazid* } & $6 \mathrm{mos}$ & $\begin{array}{l}\text { Adults: } 5 \mathrm{mg} / \mathrm{kg} \\
\text { Children: } 10-20 \mathrm{mg} / \mathrm{kg}^{\dagger \dagger} \\
\text { Maximum dose: } 300 \mathrm{mg} \\
\text { Adults: } 15 \mathrm{mg} / \mathrm{kg} \\
\text { Children: } 20-40 \mathrm{mg} / \mathrm{kg}^{\dagger \dagger} \\
\text { Maximum dose: } 900 \mathrm{mg}\end{array}$ & $\begin{array}{l}\text { Daily } \\
\text { Twice weekly }\end{array}$ & 180 \\
\hline & $9 \mathrm{mos}$ & $\begin{array}{l}\text { Adults: } 5 \mathrm{mg} / \mathrm{kg} \\
\text { Children: } 10-20 \mathrm{mg} / \mathrm{kg}^{\dagger \dagger} \\
\text { Maximum dose: } 300 \mathrm{mg} \\
\text { Adults: } 15 \mathrm{mg} / \mathrm{kg} \\
\text { Children: } 20-40 \mathrm{mg} / \mathrm{kg}^{\dagger \dagger} \\
\text { Maximum dose: } 900 \mathrm{mg}\end{array}$ & $\begin{array}{l}\text { Daily } \\
\text { Twice weekly§ }\end{array}$ & 270 \\
\hline
\end{tabular}

\footnotetext{
* Isoniazid is formulated as 100-mg and 300-mg tablets.

${ }^{\dagger}$ Rifapentine is formulated as 150-mg tablets in blister packs that should be kept sealed until use.

$\S$ Intermittent regimens must be provided via directly observed therapy (i.e., a health care worker observes the ingestion of medication).

" Rifampin (rifampicin) is formulated as 150-mg and 300-mg capsules.

** The American Academy of Pediatrics acknowledges that some experts use rifampin at $20-30 \mathrm{mg} / \mathrm{kg}$ for the daily regimen when prescribing for infants and toddlers (Source: American Academy of Pediatrics. Tuberculosis. In: Kimberlin DW, Brady MT, Jackson MA, Long SS, eds. Red Book: 2018 Report of the Committee on Infectious Diseases. 31st ed. Itasca, IL: American Academy of Pediatrics; 2018:829-53).

${ }^{+\dagger}$ The American Academy of Pediatrics recommends an isoniazid dosage of 10-15 mg/kg for the daily regimen and $20-30 \mathrm{mg} / \mathrm{kg}$ for the twice-weekly regimen.
}

for asymptomatic or subclinical TB disease increases, possibly facilitating rifampin resistance if TB disease is inadvertently treated with rifampin monotherapy (89).

\section{Three Months of Daily Isoniazid Plus Rifampin}

A regimen of 3 months of daily isoniazid plus rifampin is a preferred treatment that is conditionally recommended for adults and children of all ages and for HIV-positive persons as 
drug interactions allow. HIV-negative adults and children with a positive tuberculin skin test (TST) who received 3 months of daily isoniazid plus rifampin appeared to have a similar risk for TB disease, hepatotoxicity, and adverse effects requiring discontinuation of therapy as those who received $\geq 6$ months of isoniazid $(23,35,44,51,90)$. Among children aged $<15$ years specifically, a 3-month course of daily isoniazid plus rifampin appeared as effective as a 6-month or longer course of isoniazid, because direct comparisons found no difference in TB disease and no differences in adverse effects requiring discontinuation of therapy or hepatotoxicity (67). In HIV-positive persons, no difference was found in the incidence of TB disease among those who received 3 months of daily isoniazid plus rifampin compared with those who received $\geq 6$ months of isoniazid monotherapy, regardless of whether they were TST positive, TST negative, or anergic $(34,46,63,72)$. Hepatotoxicity was less frequent among those receiving the shorter course of therapy, although discontinuation of therapy because of adverse effects was more frequent (63).

Potential drug interactions with rifampin and acquired drug resistance if $\mathrm{TB}$ disease is not adequately excluded also are important considerations (see previous section on 4 months of daily rifampin). In addition, hepatotoxicity risk might be greater with the two drugs given together than with either drug given alone (91).

\section{Alternative Regimens: Six or Nine Months of Daily Isoniazid}

Regimens of 6 or 9 months of daily isoniazid are alternative recommended regimens; 6 months daily is strongly recommended for HIV-negative adults and children of all ages and conditionally for HIV-positive adults and children of all ages and 9 months daily is conditionally recommended for adults and children of all ages, both HIV-negative and HIV-positive. Isoniazid reduces the risk for developing TB disease in persons with a positive TST, including HIV-negative adults and children $(7,23,28,43,47,73)$, HIV-positive adults $(27,38,42,46,60,72)$, and presumably also HIV-positive children. The drug can cause hepatotoxicity and be associated with discontinuation because of adverse effects, although these effects are more common in adults than children $(23,43)$.

In HIV-positive persons who have a negative TST, anergy, or an unknown TST, the benefit of isoniazid is uncertain in settings with low TB incidence (38). For these HIV-positive persons, the potential exists for a reduction in the incidence of TB disease and an increase in adverse effects with isoniazid therapy; however, the likelihood of these effects remains uncertain because of wide confidence intervals resulting from too few events.
The evidence synthesis included multiple durations of isoniazid therapy in persons with a positive TST $(3,6$, and 12 months in HIV-negative persons and 6 months in HIVpositive persons) (7,72). Among HIV-negative persons with inactive TB (defined as the presence of tuberculin positivity, stable fibrotic lung lesions, and negative sputum cultures in persons not previously treated), 6 and 12 months of therapy were more effective than 3 months of therapy, demonstrating the benefit of LTBI treatment with isoniazid in this high-risk subset of patients with LTBI ( 7 ). Studies of other regimens have persons with LTBI and fibrotic lesions but in much smaller numbers $(14,68)$. According to the results of the systematic review process, among HIV-positive persons, 6 months of therapy was highly effective (72), and the effect of other durations was unknown. Also reviewed was an analysis that included different, fewer trials than included in this report and found that 9 months of daily isoniazid therapy was perhaps more effective than 6 months and similar to 12 months (25,92-94). However, no clinical trial data were available directly comparing 9 months of isoniazid to placebo, 6 months of isoniazid, or 12 months of isoniazid.

Among HIV-positive persons living in areas with a high TB incidence, isoniazid is complementary to antiretroviral therapy in preventing TB disease. Two randomized controlled trials have demonstrated that isoniazid plus antiretroviral therapy decreased the incidence of TB disease to a greater extent than either isoniazid alone or antiretroviral therapy alone $(27,61)$. Potential disadvantages of the regimen include its long duration, hepatoxicity, and low treatment completion rates (primarily due to the first two factors).

\section{Discussion}

A systematic literature review was performed of clinical trial data pertaining to effectiveness and toxicity of treatment of LTBI, including studies published since the 2018 World Health Organization LTBI guidelines (95). Evidence quality was evaluated using the GRADE approach, and a network metaanalysis was performed, updated to include data from studies published since a previous network meta-analysis (10), to compare regimens not evaluated head-to-head in clinical trials.

Recommendations were formulated on the basis of the balance of desirable and undesirable consequences of the intervention, the quality of evidence, patient values and preferences, and feasibility. These factors also informed the priority rank of the regimens as preferred or alternative, with preference for shorter regimens, given their similar efficacy compared with 6-9 months of isoniazid but favorable tolerability and higher treatment completion rates. This combination of characteristics 
should result in greater effectiveness of the shorter regimens in clinical settings. More effective treatment of LTBI will facilitate TB elimination (96). Prescribing providers or pharmacists who are unfamiliar with rifampin and rifapentine might confuse the two drugs. They are not interchangeable, and caution should be taken to ensure that patients receive the correct medication for the intended regimen.

Although 9 months of isoniazid was a preferred regimen in the guidelines published in 2000, both 6 and 9 months of isoniazid were recommended at that time (8). In these current guidelines, application of GRADE criteria resulted in a strong recommendation for 6 months of isoniazid as an alternative for those persons unable to take a shorter preferred regimen (e.g., due to drug intolerability or drug-drug interactions), particularly in HIV-negative persons. The longer duration of isoniazid could increase the risk for hepatotoxicity and although increased effectiveness is plausible, the two treatment durations have not been directly compared.

Two months of rifampin plus pyrazinamide are not recommended for treatment of LTBI because of the hepatotoxicity risk. However, in persons treated empirically for TB disease with isoniazid, rifampin, and pyrazinamide for 2 months, this regimen will effectively treat LTBI in persons subsequently determined to have LTBI rather than TB disease.

\section{Other Considerations}

Following are several considerations for the use of these guidelines. First, the committee did not include costeffectiveness in evaluating the evidence; recommendations were based on evaluating effectiveness and toxicity of the regimens. Second, the committee did not evaluate evidence regarding how to implement these regimens programmatically (e.g., who to test and treat and management of side effects). Third, these guidelines focus on treatment regimens for persons with LTBI living in countries with low TB disease incidence. These guidelines do not address other empiric TB prevention strategies (e.g., 1 month of isoniazid plus rifapentine among HIV-positive persons living in settings with a high TB incidence regardless of results from the TST or an interferongamma release assay) (97). Finally, shorter regimens should not be used for patients in whom rifamycins are contraindicated, including those taking medications with significant drug-drug interactions with rifamycins.

\section{Conclusion}

For patients without drug intolerability or drug-drug interactions, short-course (3-4 months) rifamycin-based treatment regimens are preferred over the longer-course (6-9 months) isoniazid monotherapy for treatment of LTBI. These guidelines can be used by clinicians, public health officials, policymakers, health care organizations, and other state and local stakeholders who might need to adapt these guidelines for individual clinical circumstances. Local and state $\mathrm{TB}$ programs in the United States answer questions about diagnosing and treating persons with LTBI in their jurisdictions (http://www.tbcontrollers.org).

\section{Acknowledgments}

Carol Hamilton, Duke University; John Jereb, National Center for HIV/AIDS, Viral Hepatitis, STD, and TB Prevention, Division of Tuberculosis Elimination, CDC; Victoria Shelus, The University of North Carolina at Chapel Hill; Ross Harris, Public Health England; 2019-2020 National Tuberculosis Controllers Association board members.

\section{Conflicts of Interest}

All authors, who are also the LTBI treatment guidelines committee members, have completed and submitted the International Committee of Medical Journal Editors form for disclosure of potential conflicts of interest. No potential conflicts of interest were disclosed.

\section{References}

1. Houben RM, Dodd PJ. The global burden of latent tuberculosis infection: a re-estimation using mathematical modelling. PLoS Med 2016;13:e1002152. https://doi.org/10.1371/journal.pmed.1002152

2. Miramontes R, Hill AN, Yelk Woodruff RS, et al. Tuberculosis infection in the United States: prevalence estimates from the National Health and Nutrition Examination Survey, 2011-2012. PLoS One 2015;10:e0140881. https://doi.org/10.1371/journal.pone.0140881

3. Sutherland I. The ten-year incidence of clinical TB following conversion in 2,550 individuals aged 14 to 19 years. Tuberculosis Surveillance Research Unit Progress Report. The Hague, the Netherlands: The Royal Netherlands Tuberculosis Foundation; 1968.

4. Sutherland I. Recent studies in the epidemiology of tuberculosis, based on the risk of being infected with tubercle bacilli. Adv Tuberc Res 1976;19:1-63.

5. Kritski AL, Marques MJ, Rabahi MF, et al. Transmission of tuberculosis to close contacts of patients with multidrug-resistant tuberculosis. Am J Respir Crit Care Med 1996;153:331-5. https://doi.org/10.1164/ ajrccm.153.1.8542139

6. Shea KM, Kammerer JS, Winston CA, Navin TR, Horsburgh CR Jr. Estimated rate of reactivation of latent tuberculosis infection in the United States, overall and by population subgroup. Am J Epidemiol 2014;179:216-25. https://doi.org/10.1093/aje/kwt246

7. International Union Against Tuberculosis Committee on Prophylaxis. Efficacy of various durations of isoniazid preventive therapy for tuberculosis: five years of follow-up in the IUAT trial. Bull World Health Organ 1982;60:555-64.

8. American Thoracic Society. CDC targeted tuberculin testing and treatment of latent tuberculosis infection. Am J Respir Crit Care Med 2000; 161:S221-47.

9. CDC; American Thoracic Society. Update: adverse event data and revised American Thoracic Society/CDC recommendations against the use of rifampin and pyrazinamide for treatment of latent tuberculosis infectionUnited States, 2003. MMWR Morb Mortal Wkly Rep 2003;52:735-9. 
10. Zenner D, Beer N, Harris RJ, Lipman MC, Stagg HR, van der Werf MJ. Treatment of latent tuberculosis infection: an updated network meta-analysis. Ann Intern Med 2017;167:248-55. https://doi. org/10.7326/M17-0609

11. Viechtbauer W. Conducting meta-analyses in $\mathrm{R}$ with the metafor package. J Stat Softw 2010;36:1-48. https://doi.org/10.18637/jss.v036.i03

12. Higgins JP, Altman DG, Gøtzsche PC, et al; Cochrane Bias Methods Group; Cochrane Statistical Methods Group. The Cochrane Collaboration's tool for assessing risk of bias in randomised trials. BMJ 2011;343:d5928. https://doi.org/10.1136/bmj.d5928

13. Diallo T, Adjobimey M, Ruslami R, et al. Safety and side effects of rifampin versus isoniazid in children. N Engl J Med 2018;379:454-63. https://doi.org/10.1056/NEJMoa1714284

14. Menzies D, Adjobimey M, Ruslami R, et al. Four months of rifampin or nine months of isoniazid for latent tuberculosis in adults. N Engl J Med 2018;379:440-53. https://doi.org/10.1056/NEJMoa1714283

15. Stagg HR, Zenner D, Harris RJ, Muñoz L, Lipman MC, Abubakar I. Treatment of latent tuberculosis infection: a network meta-analysis. Ann Intern Med 2014;161:419-28. https://doi.org/10.7326/M14-1019

16. Brooks SP. MCMC convergence diagnosis via multivariate bounds on log-concave densities. Ann Stat 1998;26:398-433. https://doi. org/10.1214/aos/1030563991

17. Dias S, Welton NJ, Sutton AJ, Ades AE. NICE DSU technical support document 2: a generalised linear modelling framework for pairwise and network meta-analysis of randomised controlled trials. London, England: National Institute for Health and Clinical Excellence; 2011.

18. Guyatt GH, Oxman AD, Vist GE, et al; GRADE Working Group. GRADE: an emerging consensus on rating quality of evidence and strength of recommendations. BMJ 2008;336:924-6. https://doi. org/10.1136/bmj.39489.470347.AD

19. Andrews J, Guyatt G, Oxman AD, et al. GRADE guidelines: 14. Going from evidence to recommendations: the significance and presentation of recommendations. J Clin Epidemiol 2013;66:719-25. https://doi. org/10.1016/j.jclinepi.2012.03.013

20. Horsburgh CR Jr, Goldberg S, Bethel J, et al; Tuberculosis Epidemiologic Studies Consortium. Latent TB infection treatment acceptance and completion in the United States and Canada. Chest 2010;137:401-9. https://doi.org/10.1378/chest.09-0394

21. Agarwal SK, Gupta S, Dash SC, Bhowmik D, Tiwari SC. Prospective randomised trial of isoniazid prophylaxis in renal transplant recipient. Int Urol Nephrol 2004;36:425-31. https://doi.org/10.1007/ s11255-004-6251-6

22. Sterling TR, Scott NA, Miro JM, et al; Tuberculosis Trials Consortium, the AIDS Clinical Trials Group for the PREVENT TB Trial (TBTC Study 26ACTG 5259) The investigators of the TB Trials Consortium and the AIDS Clinical Trials Group for the PREVENT TB Trial are listed in the Supplement, item 17 . Three months of weekly rifapentine and isoniazid for treatment of Mycobacterium tuberculosis infection in HIV-coinfected persons. AIDS 2016;30:1607-15. https://doi. org/10.1097/QAD.0000000000001098

23. Hong Kong Chest Service/Tuberculosis Research Centre, Madras/British Medical Research Council. A double-blind placebo-controlled clinical trial of three antituberculosis chemoprophylaxis regimens in patients with silicosis in Hong Kong. Am Rev Respir Dis 1992;145:36-41. https://doi.org/10.1164/ajrccm/145.1.36

24. Bush OB Jr, Sugimoto M, Fujii Y, Brown FA Jr. Isoniazid prophylaxis in contacts of persons with known tuberculosis. Second report. Am Rev Respir Dis 1965;92:732-40.

25. Comstock GW, Ferebee SH, Hammes LM. A controlled trial of community-wide isoniazid prophylaxis in Alaska. Am Rev Respir Dis 1967;95:935-43.

26. Cowie RL. Short course chemoprophylaxis with rifampicin, isoniazid and pyrazinamide for tuberculosis evaluated in gold miners with chronic silicosis: a double-blind placebo controlled trial. Tuber Lung Dis 1996;77:239-43. https://doi.org/10.1016/S0962-8479(96)90007-6
27. Danel C, Moh R, Gabillard D, et al; TEMPRANO ANRS 12136 Study Group. A trial of early antiretrovirals and isoniazid preventive therapy in Africa. N Engl J Med 2015;373:808-22. https://doi.org/10.1056/ NEJMoa1507198

28. Debre R, Perdrizet S, Lotte A, Naveau M, Lert F. Isoniazid chemoprophylaxis of latent primary tuberculosis: in five trial centres in France from 1959 to 1969. Int J Epidemiol 1973;2:153-60. https:// doi.org/10.1093/ije/2.2.153

29. Del Castillo H, Bautista L, Jacinto C, Lorenzo C, Lapuz S, Legaspi B. Chemoprophylaxis in the Philippines: a controlled pilot study among household contacts of tuberculosis cases. Bull Quezon Institute 1965;7:277-90.

30. Egsmose T, Ang'awa JO, Poti SJ. The use of isoniazid among household contacts of open cases of pulmonary tuberculosis. Bull World Health Organ 1965;33:419-33.

31. Falk A, Fuchs GF. Prophylaxis with isoniazid in inactive tuberculosis. A Veterans Administration cooperative study XII. Chest 1978;73:44-8. https://doi.org/10.1378/chest.73.1.44

32. Ferebee SH, Mount FW. Tuberculosis morbidity in a controlled trial of the prophylactic use of isoniazid among household contacts. Am Rev Respir Dis 1962;85:490-510.

33. Ferebee SH, Mount FW, Murray FJ, Livesay VT. A controlled trial of isoniazid prophylaxis in mental institutions. Am Rev Respir Dis 1963;88:161-75.

34. Fitzgerald DW, Severe P, Joseph P, et al. No effect of isoniazid prophylaxis for purified protein derivative-negative HIV-infected adults living in a country with endemic tuberculosis: results of a randomized trial. J Acquir Immune Defic Syndr 2001;28:305-7. https://doi. org/10.1097/00042560-200111010-00018

35. Geijo MP, Herranz CR, Vaño D, García AJ, García M, Dimas JF. [Shortcourse isoniazid and rifampin compared with isoniazid for latent tuberculosis infection: a randomized clinical trial]. Enferm Infecc Microbiol Clin 2007;25:300-4.

36. Gordin F, Chaisson RE, Matts JP, et al. Rifampin and pyrazinamide vs isoniazid for prevention of tuberculosis in HIV-infected persons: an international randomized trial. JAMA 2000;283:1445-50. https://doi. org/10.1001/jama.283.11.1445

37. Gordin FM, Cohn DL, Matts JP, et al; CDC. Hepatotoxicity of rifampin and pyrazinamide in the treatment of latent tuberculosis infection in HIV-infected persons: is it different than in HIV-uninfected persons? Clin Infect Dis 2004;39:561-5. https://doi.org/10.1086/422724

38. Gordin FM, Matts JP, Miller C, et al; Terry Beirn Community Programs for Clinical Research on AIDS. A controlled trial of isoniazid in persons with anergy and human immunodeficiency virus infection who are at high risk for tuberculosis. N Engl J Med 1997;337:315-20. https://doi. org/10.1056/NEJM199707313370505

39. Gray DM, Workman LJ, Lombard CJ, et al. Isoniazid preventive therapy in HIV-infected children on antiretroviral therapy: a pilot study. Int J Tuberc Lung Dis 2014;18:322-7. https://doi.org/10.5588/ijtld.13.0354

40. Gupta D, Kumar R, Nath N, Kothari A. Chemoprophylaxis in high risk children analysis of 8 years' follow up: preliminary report. Indian J Tuberc 1993;40:125-7.

41. Halsey NA, Coberly JS, Desormeaux J, et al. Randomised trial of isoniazid versus rifampicin and pyrazinamide for prevention of tuberculosis in HIV-1 infection. Lancet 1998;351:786-92. https://doi. org/10.1016/S0140-6736(97)06532-X

42. Hawken MP, Meme HK, Elliott LC, et al. Isoniazid preventive therapy for tuberculosis in HIV-1-infected adults: results of a randomized controlled trial. AIDS 1997;11:875-82. https://doi. org/10.1097/00002030-199707000-00006

43. Horwitz O, Payne PG, Wilbek E. Epidemiological basis of tuberculosis eradication. 4. The isoniazid trial in Greenland. Bull World Health Organ 1966;35:509-26. 
44. Jiménez-Fuentes MA, de Souza-Galvao ML, Mila Augé C, Solsona Peiró J, Altet-Gómez MN. Rifampicin plus isoniazid for the prevention of tuberculosis in an immigrant population. Int J Tuberc Lung Dis 2013;17:326-32. https://doi.org/10.5588/ijtld.12.0510

45. John GT, Thomas PP, Thomas M, Jeyaseelan L, Jacob CK, Shastry JC. A double-blind randomized controlled trial of primary isoniazid prophylaxis in dialysis and transplant patients. Transplantation 1994;57:1683-4. https://doi.org/10.1097/00007890-199457110-00029

46. Johnson JL, Okwera A, Hom DL, et al; Uganda-Case Western Reserve University Research Collaboration. Duration of efficacy of treatment of latent tuberculosis infection in HIV-infected adults. AIDS 2001;15:2137-47. https://doi.org/10.1097/00002030-200111090-00009

47. Kim SH, Lee SO, Park IA, et al. Isoniazid treatment to prevent TB in kidney and pancreas transplant recipients based on an interferon- $\gamma$ releasing assay: an exploratory randomized controlled trial. J Antimicrob Chemother 2015;70:1567-72. https://doi.org/10.1093/jac/dku562

48. Ma L, Lin B, Wang L, Wang D, Li G, Wang G. [Preventive therapy for iatrogenic active tuberculosis in systemic lupus erythematosus patients]. Zhonghua Yi Xue Za Zhi 2014;94:3579-82.

49. Madhi SA, Nachman S, Violari A, et al; P1041 Study Team. Primary isoniazid prophylaxis against tuberculosis in HIV-exposed children. N Engl J Med 2011;365:21-31. https://doi.org/10.1056/ NEJMoa1011214

50. Magdorf K, Arizzi-Rusche AF, Geiter LJ, O’Brien RJ, Wahn U. [Compliance and tolerance of new antitubercular short-term chemopreventive regimens in childhood-a pilot project]. Pneumologie 1994; $48: 761-4$

51. Martínez Alfaro E, Solera J, Serna E, et al. [Compliance, tolerance and effectiveness of a short chemoprophylaxis regimen for the treatment of tuberculosis]. Med Clin (Barc) 1998;111:401-4.

52. Martínez Alfaro EM, Cuadra F, Solera J, et al; The GECMEI Group. [Evaluation of 2 tuberculosis chemoprophylaxis regimens in patients infected with human immunodeficiency virus]. Med Clin (Barc) 2000;115:161-5.

53. Martinson NA, Barnes GL, Moulton LH, et al. New regimens to prevent tuberculosis in adults with HIV infection. N Engl J Med 2011;365:11-20. https://doi.org/10.1056/NEJMoa1005136

54. Matteelli A, Olliaro P, Signorini L, et al. Tolerability of twice-weekly rifabutin-isoniazid combinations versus daily isoniazid for latent tuberculosis in HIV-infected subjects: a pilot study. Int J Tuberc Lung Dis 1999;3:1043-6.

55. Mohammed A, Myer L, Ehrlich R, Wood R, Cilliers F, Maartens G. Randomised controlled trial of isoniazid preventive therapy in South African adults with advanced HIV disease. Int J Tuberc Lung Dis 2007;11:1114-20.

56. Mount FW, Ferebee SH. The effect of isoniazid prophylaxis on tuberculosis morbidity among household contacts of previously known cases of tuberculosis. Am Rev Respir Dis 1962;85:821-7.

57. Naqvi R, Naqvi A, Akhtar S, et al. Use of isoniazid chemoprophylaxis in renal transplant recipients. Nephrol Dial Transplant 2010;25:634-7. https://doi.org/10.1093/ndt/gfp489

58. Pape JW, Jean SS, Ho JL, Hafner A, Johnson WD Jr. Effect of isoniazid prophylaxis on incidence of active tuberculosis and progression of HIV infection. Lancet 1993;342:268-72. https://doi. org/10.1016/0140-6736(93)91817-6

59. Portilla J, Jordá P, Esteban J, Sánchez-Payá J, Merino E, Boix V; Grupo de Estudio Protocolo-INH. [Directly observed treatment of latent tuberculosis infection: comparative study of two isoniazid regimens]. Enferm Infecc Microbiol Clin 2003;21:293-5. https://doi.org/10.1016/ S0213-005X(03)72943-7

60. Quigley MA, Mwinga A, Hosp M, et al. Long-term effect of preventive therapy for tuberculosis in a cohort of HIVinfected Zambian adults. AIDS 2001;15:215-22. https://doi. org/10.1097/00002030-200101260-00011
61. Rangaka MX, Wilkinson RJ, Boulle A, et al. Isoniazid plus antiretroviral therapy to prevent tuberculosis: a randomised double-blind, placebocontrolled trial. Lancet 2014;384:682-90. https://doi.org/10.1016/ S0140-6736(14)60162-8

62. Rivero A, López-Cortés L, Castillo R, et al; Grupo Andaluz para el estudio de las Enfermedades Infecciosas (GAEI). [Randomized trial of three regimens to prevent tuberculosis in HIV-infected patients with anergy]. Enferm Infecc Microbiol Clin 2003;21:287-92. https://doi. org/10.1016/S0213-005X(03)72942-5

63. Rivero A, López-Cortés L, Castillo R, et al; Grupo Andaluz para el estudio de las Enfermedades Infecciosas (GAEI). [Randomized clinical trial investigating three chemoprophylaxis regimens for latent tuberculosis infection in HIV-infected patients]. Enferm Infecc Microbiol Clin 2007;25:305-10. https://doi.org/10.1157/13102265

64. Samandari T, Agizew TB, Nyirenda S, et al. Tuberculosis incidence after 36 months' isoniazid prophylaxis in HIV-infected adults in Botswana: a posttrial observational analysis. AIDS 2015;29:351-9. https://doi. org/10.1097/QAD.0000000000000535

65. Samandari T, Agizew TB, Nyirenda S, et al. 6-month versus 36-month isoniazid preventive treatment for tuberculosis in adults with HIV infection in Botswana: a randomised, double-blind, placebo-controlled trial. Lancet 2011;377:1588-98. https://doi.org/10.1016/ S0140-6736(11)60204-3

66. Schechter M, Zajdenverg R, Falco G, et al. Weekly rifapentine/isoniazid or daily rifampin/pyrazinamide for latent tuberculosis in household contacts. Am J Respir Crit Care Med 2006;173:922-6. https://doi. org/10.1164/rccm.200512-1953OC

67. Spyridis NP, Spyridis PG, Gelesme A, et al. The effectiveness of a 9-month regimen of isoniazid alone versus 3-and 4-month regimens of isoniazid plus rifampin for treatment of latent tuberculosis infection in children: results of an 11-year randomized study. Clin Infect Dis 2007;45:715-22. https://doi.org/10.1086/520983

68. Sterling TR, Villarino ME, Borisov AS, et al; TB Trials Consortium PREVENT TB Study Team. Three months of rifapentine and isoniazid for latent tuberculosis infection. N Engl J Med 2011;365:2155-66. https://doi.org/10.1056/NEJMoa1104875

69. Swaminathan S, Menon PA, Gopalan N, et al. Efficacy of a six-month versus a 36-month regimen for prevention of tuberculosis in HIVinfected persons in India: a randomized clinical trial. PLoS One 2012;7:e47400. https://doi.org/10.1371/journal.pone.0047400

70. Veening GJ. Long term isoniazid prophylaxis. Controlled trial on INH prophylaxis after recent tuberculin conversion in young adults. Bull Int Union Tuberc 1968;41:169-71.

71. Vikrant S, Agarwal SK, Gupta S, et al. Prospective randomized control trial of isoniazid chemoprophylaxis during renal replacement therapy. Transpl Infect Dis 2005;7:99-108. https://doi. org/10.1111/j.1399-3062.2005.00103.x

72. Whalen CC, Johnson JL, Okwera A, et al; Uganda-Case Western Reserve University Research Collaboration. A trial of three regimens to prevent tuberculosis in Ugandan adults infected with the human immunodeficiency virus. N Engl J Med 1997;337:801-8. https://doi. org/10.1056/NEJM199709183371201

73. Xie QB, Wen FQ, Yin G. [Isoniazid prophylaxis for pulmonary tuberculosis in Chinese patients with rheumatoid arthritis receiving long-term methotrexate therapy]. Sichuan Da Xue Xue Bao Yi Xue Ban 2009;40:138-40.

74. Zar HJ, Cotton MF, Strauss S, et al. Effect of isoniazid prophylaxis on mortality and incidence of tuberculosis in children with HIV: randomised controlled trial. BMJ 2007;334:136. https://doi. org/10.1136/bmj.39000.486400.55

75. Bailey WC, Weill H, DeRouen TA, Ziskind MM, Jackson HA. The effect of isoniazid on transaminase levels. Ann Intern Med 1974;81:200-2. https://doi.org/10.7326/0003-4819-81-2-200 
76. Chan PC, Yang CH, Chang LY, et al. Latent tuberculosis infection treatment for prison inmates: a randomised controlled trial. Int J Tuberc Lung Dis 2012;16:633-8. https://doi.org/10.5588/ijtld.11.0504

77. Leung CC, Law WS, Chang KC, et al. Initial experience on rifampin and pyrazinamide vs isoniazid in the treatment of latent tuberculosis infection among patients with silicosis in Hong Kong. Chest 2003;124:2112-8. https://doi.org/10.1378/chest.124.6.2112

78. Menzies D, Dion MJ, Rabinovitch B, Mannix S, Brassard P, Schwartzman $\mathrm{K}$. Treatment completion and costs of a randomized trial of rifampin for 4 months versus isoniazid for 9 months. Am J Respir Crit Care Med 2004;170:445-9. https://doi.org/10.1164/rccm.200404-478OC

79. Menzies D, Long R, Trajman A, et al. Adverse events with 4 months of rifampin therapy or 9 months of isoniazid therapy for latent tuberculosis infection: a randomized trial. Ann Intern Med 2008;149:689-97. https://doi.org/10.7326/0003-4819-149-10-200811180-00003

80. Sánchez-Arcilla I, Vílchez JM, García de la Torre M, Fernández X, Noguerado A. [Treatment of latent tuberculosis among homeless population. Comparison between two therapeutic approaches]. Med Clin (Barc) 2004;122:57-9.

81. Tortajada C, Martínez-Lacasa J, Sánchez F, et al; Tuberculosis Prevention Working Group. Is the combination of pyrazinamide plus rifampicin safe for treating latent tuberculosis infection in persons not infected by the human immunodeficiency virus? Int J Tuberc Lung Dis 2005;9:276-81.

82. White MC, Tulsky JP, Lee JR, et al. Isoniazid vs. rifampin for latent tuberculosis infection in jail inmates: toxicity and adherence. J Correct Health Care 2012;18:131-42. https://doi.org/10.1177/1078345811435973

83. Villarino ME, Scott NA, Weis SE, et al; International Maternal Pediatric and Adolescents AIDS Clinical Trials Group; Tuberculosis Trials Consortium. Treatment for preventing tuberculosis in children and adolescents: a randomized clinical trial of a 3-month, 12-dose regimen of a combination of rifapentine and isoniazid. JAMA Pediatr 2015;169:247-55. https://doi.org/10.1001/jamapediatrics.2014.3158

84. Belknap R, Holland D, Feng PJ, et al; TB Trials Consortium iAdhere Study Team. Self-administered versus directly observed once-weekly isoniazid and rifapentine treatment of latent tuberculosis infection: a randomized trial. Ann Intern Med 2017;167:689-97. https://doi. org/10.7326/M17-1150

85. Borisov AS, Bamrah Morris S, Njie GJ, et al. Update of recommendations for use of once-weekly isoniazid-rifapentine regimen to treat latent Mycobacterium tuberculosis infection. MMWR Morb Mortal Wkly Rep 2018;67:723-6. https://doi.org/10.15585/mmwr.mm6725a5
86. Sterling TR, Moro RN, Borisov AS, et al; Tuberculosis Trials Consortium. Flu-like and other systemic drug reactions among persons receiving weekly rifapentine plus isoniazid or daily isoniazid for treatment of latent tuberculosis infection in the PREVENT tuberculosis study. Clin Infect Dis 2015;61:527-35. https://doi.org/10.1093/cid/civ323

87. Baciewicz AM, Chrisman CR, Finch CK, SelfTH. Update on rifampin, rifabutin, and rifapentine drug interactions. Curr Med Res Opin 2013;29:1-12. https://doi.org/10.1185/03007995.2012.747952

88. Williamson B, Dooley KE, Zhang Y, Back DJ, Owen A. Induction of influx and efflux transporters and cytochrome P450 3A4 in primary human hepatocytes by rifampin, rifabutin, and rifapentine. Antimicrob Agents Chemother 2013;57:6366-9. https://doi.org/10.1128/ AAC.01124-13

89. Mtei L, Matee M, Herfort O, et al. High rates of clinical and subclinical tuberculosis among HIV-infected ambulatory subjects in Tanzania. Clin Infect Dis 2005;40:1500-7. https://doi.org/10.1086/429825

90. Ena J, Valls V. Short-course therapy with rifampin plus isoniazid, compared with standard therapy with isoniazid, for latent tuberculosis infection: a meta-analysis. Clin Infect Dis 2005;40:670-6. https://doi. org/10.1086/427802

91. Steele MA, Burk RF, DesPrez RM. Toxic hepatitis with isoniazid and rifampin. A meta-analysis. Chest 1991;99:465-71. https://doi. org/10.1378/chest.99.2.465

92. Comstock GW. How much isoniazid is needed for prevention of tuberculosis among immunocompetent adults? Int J Tuberc Lung Dis 1999;3:847-50.

93. Ferebee SH. Controlled chemoprophylaxis trials in tuberculosis. A general review. Bibl Tuberc 1970;26:28-106.

94. Comstock GW, Baum C, Snider DE Jr. Isoniazid prophylaxis among Alaskan Eskimos: a final report of the bethel isoniazid studies. Am Rev Respir Dis 1979;119:827-30.

95. World Health Organization. Latent tuberculosis infection: updated and consolidated guidelines for programmatic management 2018. https:// www.who.int/tb/publications/2018/latent-tuberculosis-infection/en

96. Abu-Raddad LJ, Sabatelli L, Achterberg JT, et al. Epidemiological benefits of more-effective tuberculosis vaccines, drugs, and diagnostics. Proc Natl Acad Sci U S A 2009;106:13980-5. https://doi.org/10.1073/ pnas.0901720106

97. Swindells S, Ramchandani R, Gupta A, et al; BRIEF TB/A5279 Study Team. One month of rifapentine plus isoniazid to prevent HIV-related tuberculosis. N Engl J Med 2019;380:1001-11. https://doi.org/10.1056/ NEJMoa1806808 


The Morbidity and Mortality Weekly Report (MMWR) Series is prepared by the Centers for Disease Control and Prevention (CDC) and is available free of charge in electronic format. To receive an electronic copy each week, visit MMWR at https://www.cdc.gov/mmwr/index.html.

Readers who have difficulty accessing this PDF file may access the HTML file at https://www.cdc.gov/mmwr/volumes/69/rr/rr6901a1.htm?s_cid=rr601a1_w. Address all inquiries about the MMWR Series, including material to be considered for publication, to Executive Editor, MMWR Series, Mailstop E-90, CDC, 1600 Clifton Rd., N.E., Atlanta, GA 30329-4027 or to mmwrq@cdc.gov.

All material in the $M M W R$ Series is in the public domain and may be used and reprinted without permission; citation as to source, however, is appreciated. MMWR and Morbidity and Mortality Weekly Report are service marks of the U.S. Department of Health and Human Services.

Use of trade names and commercial sources is for identification only and does not imply endorsement by the U.S. Department of Health and Human Services.

References to non-CDC sites on the Internet are provided as a service to $M M W R$ readers and do not constitute or imply endorsement of these organizations or their programs by CDC or the U.S. Department of Health and Human Services. CDC is not responsible for the content of these sites. URL addresses listed in $M M W R$ were current as of the date of publication.

ISSN: 0149-2195 (Print) 